\title{
Effects of Soil Moisture on Burned and Clipped Idaho Fescue
}

\author{
C.M. BRITTON, R.G. CLARK, AND F.A. SNEVA
}

\begin{abstract}
Idaho fescue (Festuca idahoensis) plants were burned and clipped under 2 soil water regimes. Treatments were applied to plants in late August and mid-October located in eastern Oregon. Results indicated that watering plants either before or after burning produced no beneficial effects as measured by changes in basal area or yield. Regardless of treatment, plant damage was greater with late August as contrasted to mid-October treatment dates. These data do not support the opinion that high soil moisture is necessary prior to fall burning of sagebrush-bunchgrass communities.
\end{abstract}

A widely accepted philosophy is to burn rangeland when the soil is moist. In his comprehensive review on range burning, Wright (1974) stated, "Ideally, a prescribed burn should be conducted during the dormant season when the soil is wet." Beardall and Sylvester (1976) listed 4 factors necessary for successful spring burning of sagebrush (Artemisia spp.) range. The first factor listed was that the soil must be wet. The wet-soil philosophy is universally accepted and has not been challenged in the literature for bunchgrass communities.

Opportunities for fall burning of Great Basin sagebrush communities may be extremely limited if wet soil is a requisite. Objectives of this study were to evaluate the effects of dormant season burning and clipping of Idaho fescue (Festuca idahoensis) under 2 soil water regimes and 2 dates.

\section{Methods}

The study area was located on the Squaw Butte Experiment Station Range Unit about $65 \mathrm{~km}$ west of Burns, Ore. Elevation is $1,370 \mathrm{~m}$ and average annual precipitation is about $30 \mathrm{~cm}$. Approximately $60 \%$ of the precipitation occurs during fall and winter, generally as snow, with $25 \%$ during May and June as rain. Soil on the study aea is a fine-loamy, mixed frigid Aridic Durixerolls.

A 0.5-ha area was fenced to exclude livestock, and 200 Idaho fescue plants were marked with wire stakes. Groups of 20 plants

\footnotetext{
Authors are associate professor and research assistant, Oregon Agricultural Experiment Station, and range scientist, Agr. Res. Serv., USDA, Burns, Ore. 97720 . Britton and Clark are currently at the Department of Range and Wildlife Management, Texas Tech University, Lubbock, Texas 79409.

This work involved a cooperative investigation of Oregon Agr. Exp. Sta. and USDA, Agr. Res. Serv. Tech. Pap. Number 6617, Oregon Agr. Exp. Sta.

Manuscript received Dec. 1, 1982.
}

were randomly assigned to 1 of 5 treatments which were applied on August 31 and October 17, 1978. Treatments were clip to 1-cm stubble height, clip then water, burn, burn then water, and water then burn. Water treatments consisted of applying a $5-\mathrm{cm}$ depth of water as a gentle spray to a $72-\mathrm{cm}$ diameter area around each plant. Water was confined to this area with a circular metal ring.

Burns were applied with a portable plant burner similar to that described by Britton and Wright (1979). Time-temperature curves peaked at $200^{\circ} \mathrm{C}$ at $30 \mathrm{sec}$. The water-then-burn plants were allowed to equilibrate for $24 \mathrm{hr}$ after irrigation before being burned.

Relative humidity, air temperature, and wind speed were measured with a belt weather kit (Fischer and Hardy 1972) at the time of burning (Table 1). Soil water contents were determined gravimetrically from 10 surface samples $(0-5 \mathrm{~cm})$ adjacent to dry and watered plants.

Treatment effects were measured as changes in basal area and yield. After treatment, each plant was photographed to determine initial base area. A wire grid ( 2.5 by $2.5 \mathrm{~cm}$ ) was placed over each plant prior to photographing to provide a permanent record of basal area. One growing season after treatment, each plant was rephotographed and percentage change in basal area calculated. Also, after one growing season, aerial biomass was clipped from each plant. Yield was expressed as $\mathrm{g} / \mathrm{dm}^{2}$ of basal area to adjust for different size plants. Mean separation was accomplished using Duncan's new multiple range test $(\alpha=0.05)$.

Table 1. Weather and soll water contents for 2 treatment dates in 1978 for burning and clipping Idaho fescue in eastern Orezon.

\begin{tabular}{lcccccc}
\hline & \multicolumn{3}{c}{ Weather } & Soil water contents \\
\cline { 2 - 5 } & \multicolumn{3}{c}{ Air } \\
& $\begin{array}{c}\text { Relative } \\
\text { humidity }\end{array}$ & $\begin{array}{c}\text { tempera- } \\
\text { ture }\end{array}$ & Wind & Dry & Watered \\
Treatment dates & $(\%)$ & $(2 \neq \mathrm{C})$ & $(\mathrm{km} / \mathrm{hr})$ & $(\%)$ & $(\%)$ \\
\hline August 31 & 31 & 25 & $3-9$ & 2.4 & 16.2 \\
October 17 & 29 & 23 & $3-8$ & 2.4 & 16.0 \\
\hline
\end{tabular}


Table 2. Mean response over treatment date for Idaho feacue observed in eastern Oregon.

\begin{tabular}{|c|c|c|c|c|c|c|c|}
\hline \multirow[b]{3}{*}{ Response } & \multicolumn{5}{|c|}{ Treatments } & & \\
\hline & \multirow{2}{*}{\multicolumn{2}{|c|}{$\begin{array}{c}\text { Clip } \\
+ \\
\text { water }\end{array}$}} & \multirow[b]{2}{*}{ Burn } & \multirow{2}{*}{$\begin{array}{c}\text { Water } \\
+ \\
\text { burn }\end{array}$} & \multirow{2}{*}{$\begin{array}{c}\text { Burn } \\
+ \\
\text { water }\end{array}$} & \multicolumn{2}{|c|}{ Means } \\
\hline & & & & & & Aug. & Oct. \\
\hline $\begin{array}{l}\text { Basal area reduction }(\%) \\
\text { Yield }\left(\mathrm{g} / \mathrm{dm}^{2}\right)\end{array}$ & $\begin{array}{r}32.8^{b} \\
2.9^{b}\end{array}$ & $\begin{array}{r}31.3^{b} \\
4.0^{a}\end{array}$ & $\begin{array}{r}42.0^{\mathrm{b}} \\
2.4^{\mathrm{bc}}\end{array}$ & $\begin{array}{l}57.1^{\mathrm{a}} \\
1.6^{\mathrm{ed}}\end{array}$ & $\begin{array}{r}59.8^{\mathrm{a}} \\
1.3^{\mathrm{d}}\end{array}$ & $\begin{array}{r}51.2 \\
2.1\end{array}$ & $\begin{array}{r}38.0 \\
2.8\end{array}$ \\
\hline
\end{tabular}

1Means within rows with similar letters are not different $(\alpha=0.05)$.

\section{Results}

Regardless of treatment, Idaho fescue was damaged less following treatment in October than in August (Table 2). Basal area reduction was about $35 \%$ less and yield was about $33 \%$ more after treatments applied in October. Based on the means taken over treatment dates, clipping was less damaging to Idaho fescue than was burning. Plants watered before or after burning produced the least regrowth and basal area reduction was greatest. Response of dry burned plants was intermediate to the wet burned and clipped treatments.

There was no difference in the basal area response of plants which were burned dry or clipped in August (Fig. 1). The clip-thenwater treatment resulted in the smallest basal-area reduction $(27 \%)$. The water-then-burn treatment was the most damaging and resulted in a $75 \%$ reduction in basal area. Because of large variation in plant responses, the burn-then-water treatment response was intermediate to the water-then-burn and clip or dry-burn treatments, and these treatments could not be statistically separated. In August, most plants watered either before or after burning initiated growth. These sprouts showed freezing damage by the first week of October.

Basal-area reduction of Idaho fescue following treatments in October was less than after August treatments, except the clipthen-water treatment which increased slightly. The burn-thenwater was the most damaging treatment with a $54 \%$ basal area reduction of Idaho fescue. Clipping was least damaging, causing a basal-area reduction of $26 \%$. The other treatments resulted in similar responses and were not statistically different.

Yield of treated plants illustrated the greater damage associated with the August than the October treatments (Fig. 2). The exception was clip-then-water, which resulted in the greatest yield regardless of treatment date. There was no difference in yields of plants which were clipped or burned in August. Lowest yields were from plants watered and burned.

Yields of more than $3 \mathrm{~g} / \mathrm{dm}^{2}$ were recorded where plants were clipped, clipped-then-watered, or burned in October. These yields

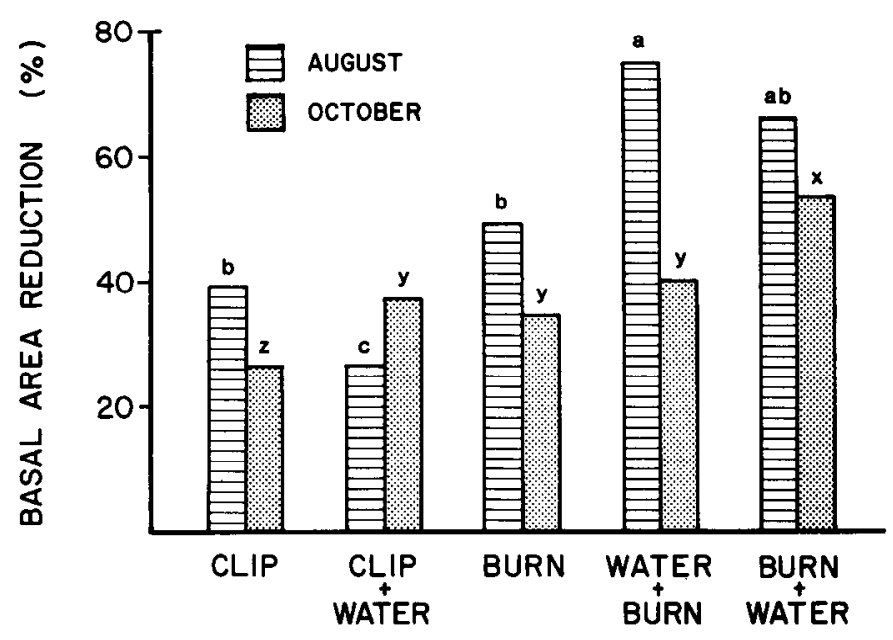

Fig. 1. Basal area reduction expressed as a percentage of the initial basal area. Within month, means separated by letters are different $(\alpha=0.05)$. were not significantly different one from the other, but were greater than the lower yields of plants watered and then burned.

\section{Discussion}

Results of this study clearly illustrate that burning in late summer will be more damaging to Idaho fescue than similar burns in the fall. Moreover, delaying prescribed burns until high soil water contents are available is not necessary or desirable for fall burns.

The marked response to date of burn was not anticipated since at the respective burn dates, plants were essentially quiescent. A period of dormancy generally is the best time to burn (Wright 1974). However, Wright (1971) found increasing resistance to burn damage for bunchgrasses in Idaho from late July through late September. This was attributed to low energy reserves and high respiration demands during late summer (Wright 1971). This trend was reversed during early fall.

The negative effect of high soil water content on plant response was suspected. Burning in the spring with high soil water status gives a positive plant response because the growing season is just starting. Burning in the late summer with high soil water contents also stimulates a growth response. However, in the Great Basin freezing night-time temperatures usually occur in late September or early October. Therefore, this winter induced growth response was terminated by the end of the growing season. By October, weather conditions were not favorable for a growth initiation response although soil moisture was available.

A possible factor contributing to the negative response of high soil water content is thermal conductivity. As soil water content increases, thermal conductivity increases. Therefore, when soil moisture is high at the time of burning, the heat pulse can reach the grass meristematic tissue faster and can remain at lethal temperatures longer (Aston and Gill 1976, Wright 1964).

Working with bunchgrasses in Idaho, Wright (1964) found watering plants prior to burning prevented deep burning into the crown and reduced percent mortality. However, dry burned plants

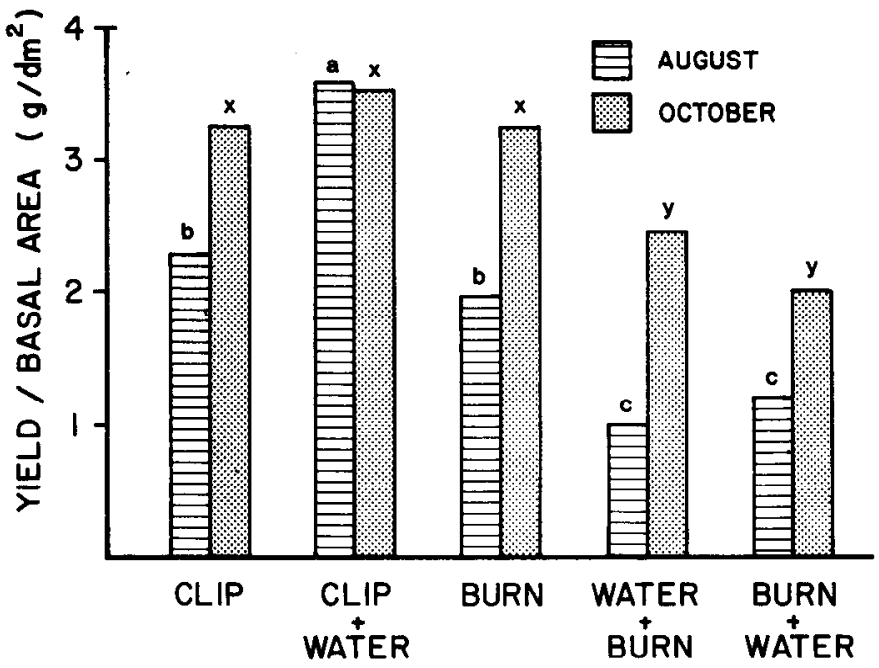

Fig. 2. Yield of treated plants in grams per square decimeter of live basal area. Within month, means separated by letters are different $(\alpha=0.05)$. 
yielded more herbage compared with watered plants. No mortality of Idaho fescue was observed in this study regardless of treatment. Future research is needed to document the point at which soil water content ceases to be important and evaluate the impact of different depths to meristematic tissue for various grass species.

From a management standpoint, this work suggests that in the Great Basin high soil water content is not necessary for fall burns where Idaho fescue is a dominant species and is probably undesirable. However, this information cannot be extrapolated to spring burning in the Great Basin as high soil water contents at growth initiation is desirable.

\section{Literature Cited}

Aston, A.R., and A.M. Gill. 1976. Coupled soil moisture, heat and water vapor transfers under simulated fire conditions. Aust. J. Soil Res. 14:55-66.

Beardall, L.E., and V.E. Sylvester. 1976. Spring burning for removal of sagebrush competition in Nevada. Proc. Tall Timbers Fire Ecol. Conf. 14:539-547.

Britton, C.M., and H.A. Wright. 1979. A portable burner for evaluating effects of fire on plants. J. Range Manage. 32:475-476.

Fischer, W.C., and C.E. Hardy. 1972. Fire-weather observers' handbook USDA Forest Serv. Inter. Mountain Forest. and Range Exp. Sta., Ogden.

Wright, H.A. 1964. An evaluation of several factors to determine why Sitanion hystrix is more resistant to burning than Stipa comata. Ph.D. Diss. Utah State Univ., Logan.

Wright, H.A. 1971. Why squirreltail is more tolerant to burning than needle-and-thread. J. Range Manage. 24:277-284.

Wright, H.A. 1974. Range burning. J. Range Manage. 27:5-11. 